A Journal of Culture, English Language, Teaching \& Literature ISSN 1414-3320 (Print), ISSN 2502-4914 (Online)

Vol. 21 No.1; June 2021

Copyright $@$ Soegijapranata Catholic University, Indonesia

\title{
EFL Learner's Literary Competence Mapping through Reader- Response Writing Assessed using CCEA GCSE Mark Scheme
}

\author{
${ }^{1}$ Suprayogi, ${ }^{2}$ Samanik, ${ }^{3}$ Elza Aqilla Novanti, and \\ ${ }^{4}$ Yoana Ardesis \\ ${ }^{1234}$ English Literature Study Program, Faculty of Arts and Education, \\ Universitas Teknokrat Indonesia, Bandarlampung, Indonesia \\ email: ${ }^{1}$ suprayogi@teknokrat.ac.id, ${ }^{2}$ samanik@teknokrat.ac.id, \\ 3elzaaqillaedu@gmail.com, ${ }^{4}$ yoanardesis@gmail.com,
}

Received: 19-10-2020

Accepted: 08-06-2021

Published: 16-06-2021 


\title{
EFL Learner's Literary Competence Mapping through Reader-Response Writing Assessed using CCEA GCSE Mark Scheme
}

\author{
${ }^{1}$ Suprayogi, ${ }^{2}$ Samanik, ${ }^{3}$ Elza Aqilla Novanti, and ${ }^{4}$ Yoana \\ Ardesis \\ ${ }^{1}$ suprayogi@teknokrat.ac.id, ${ }^{2}$ samanik@teknokrat.ac.id, \\ 3elzaaqillaedu@gmail.com, ${ }^{4}$ yoanardesis@gmail.com, \\ ${ }^{1234}$ English Literature Study Program, Faculty of Arts and \\ Education, Universitas Teknokrat Indonesia, \\ Bandarlampung, Indonesia
}

\begin{abstract}
In literary education, literary competence lies in important position as it reflects students' critical thinking ability to understand text as a whole and connect it to both their experience and social phenomenon. Recently, the research on literary competence focuses on the implementation of reader-response writing; however, it rarely highlights the importance of literary competence mapping through the quantification of the responses. This research aims at revealing the implementation of students' literary competence mapping by using reader-response writing and The Council for the Curriculum Examinations and Assessment (CCEA) General Certificate of Secondary Education (GCSE) Mark Scheme for literature subject for the assessment. Seven reader response strategies by Beach and Marshal (1991) were used as the framework. Selecting 21 students of English Literature in Prose Analysis class as the research object, this research employed qualitative descriptive method. The result shows, in completing seven reader responses, students provide various answers reflecting their ability to get into the stories. The students mostly find it difficult to describe setting of place and time and their influence to the plot of the story. In assessment process, several adjustments on distributing points of CCEA GCSE Mark Scheme for literature subject. Mark Scheme in each strategy have been made. Almost half of the students are in the band 4 and band 5 meanwhile the rest of them are in band 2 and band 3. This
\end{abstract}


research concludes that reader-response writing and CCEA GCSE Mark Scheme can be alternative to map the students' literary competence. The research further suggest that the students should be exposed more on the analysis of setting and on the argumentation building on how they should provide sufficient reason and textual evidence. In addition, the lecturer should also emphasize the expected competence level the English Literature students should acquire.

Key words: CCEA GSCE Mark Scheme, literary competence mapping, literature teaching, reader-response writing

\begin{abstract}
Abstrak: Dalam pendidikan sastra, kompetensi sastra berada pada posisi penting karena mencerminkan kemampuan berpikir kritis siswa untuk memahami teks secara utuh dan menghubungkannya dengan pengalaman dan fenomena di masyarakat. Penelitian tentang kompetensi sastra saat ini difokuskan pada penerapan tulisan respon pembaca, namun jarang menyoroti pentingnya pemetaan kompetensi sastra melalui penilaian kuantitatif pada setiap responnya. Penelitian ini bertujuan untuk mendeskripsikan implementasi pemetaan kompetensi sastra siswa dengan menggunakan tulisan respon pembaca dan skema penilaian dari The Council for the Curriculum Examinations and Assessment (CCEA) General Certificate of Secondary Education (GCSE) bidang. Tujuh reader-response strategies milik Beach dan Marshal (1991) digunakan untuk sebagai kerangka penelitian. Dengan memilih 21 Mahasiswa Sastra Inggris kelas Analisis Prosa sebagai objek penelitian, penelitian ini menggunakan metode deskriptif kualitatif. Hasil penelitian menunjukkan bahwa dalam menyelesaikan tujuh respon pembaca, siswa memberikan jawaban yang bervariasi yang mencerminkan kemampuan mereka dalam mendalami cerita. Mahasiswa kebanyakan kesulitan untuk mendeskripsikan latar tempat dan waktu serta pengaruh mereka terhadap alur cerita. Dalam proses penilaian telah dilakukan beberapa penyesuaian pada pembagian skor pada skema penilaian CCEA GCSE di setiap strategi respon pembaca. Hampir separuh siswa berada di band 4 dan band 5 sedangkan sisanya di band 2 dan band 3. Hasil penelitian ini menyimpulkan bahwa reader-response writing dan CCEA GCSE Mark Scheme dapat menjadi alternatif untuk memetakan kompetensi sastra siswa. Penelitian lebih lanjut menyarankan bahwa siswa harus diekspos lebih banyak tentang analisis pengaturan dan pada bangunan argumentasi tentang bagaimana mereka harus memberikan alasan yang cukup dan bukti tekstual. Selain itu, dosen juga harus menekankan pada tingkat kompetensi yang diharapkan mahasiswa Sastra Inggris.
\end{abstract}


Competence Mapping through Reader-Response Writing Assessed using CCEA GCSE Mark Scheme

Kata kunci: skema penilaian CCEA GCSE, pemetaan kompetensi sastra, pengajaran sastra, strategi respon pembaca

\section{INTRODUCTION}

Story exists along with the experience and civilization of humans. It can be an event that is really happening or merely a fiction (Denning, 2020). Furthermore, it contains life experience storage, the capture of historic moments and depiction of diverse views of issue. Mladkova, (2013) also believes that story can create certain identity and change social practices. Containing many aspects of reflections, therefore, a story has a power to influence its readers' thoughts. Boong (2012) stated that readers have experience-taking on feeling the emotions and thoughts as similar as them. This is how reading stories serves as entertaining purposes.

In the classroom setting, the story serves more than entertaining purposes. It educates the students to have expected characters, and narrates the milestone moments how certain concepts are established and invented. As Gomez-Rodriguez (2018) stated that stories as literary works are seen as an authentic language in use that allows learners to understand diverse cultural beliefs, values, lifestyles, and ideologies as well as to promote intercultural awareness and social and affective skills. Therefore, story serves affective function. Story also serves language learning function because through story reading in English, students can acquire language (Prahaladaiah, 2018) and further becomes additional language input source besides classroom language students can have (Afifudin, 2019). This process of knowledge acquisition should not only from the teacher or lecturer, but also from the discovery from the students themselves (Samanik, 2018).

Knowing that English is the important commodity of the students for the future (Suprayogi \& Pranoto, 2019), story reading is widely used in English classroom. Further, comprehending the story in classroom setting could also sharpen the students' critical thinking through the exploration (Norris and Phillips, 1987, in Aloqaili, 2012) which means the readers try to connect and relate ideas one another in the story reflected in personal experiences and the world they perceive. Especially within four language skill learning, critical thinking becomes crucial when the students have circulation of power over themselves, the text and beyond the text (Afifudin, 2016). Critical thinking, especially for students in English literature major, is plotted in a crucial position. These students in their graduate profile and learning outcome of their 
curriculum are expected to be able to explain, interpret as well as to connect some phenomena in the story to the current situation in the form of literary analysis as the foundation to compose other literary appreciation works. To conclude, critical thinking is a must skill that literature students should possess as the foundation of establishing literary competence.

Literary competence itself is defined as the ability to respond literary works to account for that response (Prahaladaiah, 2018). It is also the ability to relate the literary works to personal experience as well as social, culture and history (Spiro, 1991). For English literature students, literary competence is believed to be outcome-based that students should be able to see literary works from the basic to complex cognitive stages, starting from the literary analysis, literary critics, literary performance to literary production. Then, the literary competence of the students should be described and are able to be measured qualitatively and quantitatively so that in the end of their study, they have the comprehensive description of their literary competence profile. Therefore, mapping the literary competence is crucial.

In pedagogical practices, literary competence in the basic level is believed to be able to observe through how students respond to a literary text. It is rooted from reader-response theory (RRT) emerged in the past believing that in responding literary text, reader should go beyond the text itself where personal experience and schemata of social world are taken into account. RRT in relation to literary competence assessment and mapping, however, have not received much attention especially for tertiary education students taking literature. Whereas, this assessment and mapping is paramount to ensure students to have high order thinking skills and the highest level of literary competence itself. To initiate this assessment method, this study attempts to reveal the implementation of mapping of the students' literary competence level through reader-response strategies by Beach \& Marshall (1991) and The Council for the Curriculum Examinations and Assessment (CCEA) General Certificate of Secondary Education (GCSE) mark scheme for literature subject (CCEA, 2017).

\section{LITERATURE REVIEW}

\section{A. Reader-Response Writing and Its Pedagogical Practices}

Louise Rosenblatt is the figure proposing reader-response theory (RRT). Rosenblatt (1982) argues that reading is a transactional process involving text 
Competence Mapping through Reader-Response Writing Assessed using CCEA GCSE Mark Scheme

and reader in a specific circumstance. RRT believes that readers think that they are a part of the story thus they have their own interpretation in reading one literary work. Then, it shows that literary work will be meaningless without the existence of the reader. Bressler (1999) further noted that textual analysis or criticism towards literary work is derived from the formula of "the reader + the texts = meaning".

Reader response theory (RRT) appears in the response to new criticism. RRT rejects new criticism which states that meaning is only derived by the text itself, and can only be found through comprehensive analytical skills (Mart, 2019). In other words, reality and personal life of the reader play significant role in meaning-making process. Then, the reader is the central agent that determine the direction and the depth of interpretation will be. Therefore, the existence of the reader is equally important to the text and the text's author. For those, meaning of the text is subjective and varied from one reader to another. Then, in literary classroom context, the parameter of assessment is not always on how close is the meaning interpreted by the teacher or the text itself, for example, but by how far students can relate the text to their world then put it verbally.

In language classroom, the significance of response-based literature instruction according to Iskhak (2015) deals with enjoyment, freedom, engagement, and language growth. It can be concluded that RRT should make student stay joyful in reading, give them freedom to find the literary text meaning, and make them acquire new vocabulary through reading. That is how researches on RRT in EFL context in Indonesia have been widely conducted recently in which RRT is seen as the method in teaching. Inand and Boldan (2018) applied RRT for English Language Teaching (ELT) preservice teachers. Ningrum (2018) used RRT to teach reading narrative text for senior high school students meanwhile Iskhak (2015) used RRT for enhancing students' affective and linguistic growth. This research strengthens the cultivation of RRT use in both language and literature.

\section{B. Literary Competence}

Competence is considered as someone's ability to perform certain tasks which can meet the desired outcome. However, this covers not only skill as Brownie, Thomas, \& Bahnisch (2011) explain that competence shows the ability of someone dealing with knowledge, understanding, skills and abilities toward something that the assessment criterion will be different depending on expected outcomes of the certain field. Therefore, in this context, literary 
competence is defined as the knowledge, understanding, skills and abilities of students toward literary text.

Throughout the history, the term literary competence has been broadly defined in many perspectives. Spiro (1991) defines literary competence as the ability to response literature through analysis, appreciation, enjoyment, as well as the ability to connect literary text to personal experience and wider sociocultural context. In other words, literary competence has several stages and directions in it. Further, according to Culler (2000) literary competence is the implicit knowledge that readers and writers bring to their encounters with texts. This implicit knowledge in this context is seen as the intersection between what the writer is intended to convey to what the reader can interpret. Thus, Žbogar (2015) has seen literary competence as cognitive activity as well as interpretation activity of readers.

Beach \& Marshall (1991) has arranged seven strategies to assess readers' literary competence namely describing, engaging, explaining, conceiving, connecting, interpreting, judging. Describing means giving the details or description toward information related to the intrinsic element in literature which are the character (major and minor character), characterization (including the consideration of physical and psychological), setting (place and time) and style.

Engaging strategy deals with how the readers try to use their feelings in reading literary works. Then the readers will be drowned through the text, imagining what will happen and feel what the characters' feelings toward the story. They comprehend the story by entering the story and think that they are part of the story, as the character inside of the story. There are three aspects that will be the discussion in this research, feeling, imagination and thought.

In the point of conceiving, the reader will deal with the reasons why the story comes up and develops in certain directions in certain settings and characterization. Also, they believe that conceiving is aimed to understand the characters, background of the story, and the language used in a story. In this activity, the readers understand about the characters by applying their knowledge of social behavior in society and cultural backgrounds.

In explaining, the reader will interpret the characters based on why the characters do something. Explaining consists of two points. Those are the character's action and agreement. Characterization will influence all the action along the narrative plot. If the characterization is cheerful, the action of the 
Competence Mapping through Reader-Response Writing Assessed using CCEA GCSE Mark Scheme

characters will be cheerful along the story, and vice versa. In other points, agreement means the opinion that readers think about the character's action. The readers will be asked if they agree or disagree toward the character's action with the reason why they choose the answer.

Connecting strategy is how readers try to connect their own experience with the experience of the characters inside of literary work. In addition, sometimes they try to connect one story to another story similar to what they read. There are six points dealing with connecting: experience, other story, film, social life, culture, and religion. The readers will be asked to connect the story with those six points.

Interpreting deals with how the readers will use the reaction, concept and connection that was created to articulate the main idea. The activity of interpreting involves the determination of symbolic meaning, themes or specific events from the literary work. In interpreting, what is being discussed is what the text is revealed. Interpretation using the generalization or the statements that being made is not the statement from the text, but it's merely the implicit meaning. Recognizing the main idea is the most important point to good comprehension.

In judging strategy, the readers make an interpretation toward the literary work. They can use their opinion to analyze the literary text, the author or the plot of the story. Thus, judging is the essence of how a reader interprets the text by using their own expectations. The readers make a judgment by using their own expectation about the short story. The story line, the author and the moral values are the points the reader will judge. The points that will become the main point of judging are storyline or plot and moral value.

\section{Literary Competence Assessment}

Of many literary competence assessments that has already been well established is the assessment from The Council for the Curriculum Examinations and Assessment (CCEA). It is a non-departmental public body (NDPB) funded by and responsible to the Department of Education (DE) of United Kingdom focusing on curriculum, examinations and assessment (CCEA, 2017). One of CCEA works is providing assessment of various subjects, one of them is English Literature, named General Certificate of Secondary Education (GCSE). This assessment is taken by 16-yearold native English students. Indonesia have not got such assessment for literature students yet. 
For CCEA GCSE English Literature, the focus aims are to shape readers to be critical and analytical by explaining the intrinsic and extrinsic element of literary works, and connect them to sociocultural and historical account (CCEA, 2017). It also encourages students to be imaginative as well as to love literary works. CCEA GCSE English Literature focuses on three units that are The Study of Prose, The Study of Drama and Poetry, The Study of Shakespeare. Each unit has Assessment Objective (AO).

In this research, The Study of Prose becomes the focus. There are two assessment objectives provided namely Assessment Objective 1 and Assessment Objective 2. Assessment Objective 1 is to respond to texts critically and imaginatively; select and evaluate relevant textual detail to illustrate and support interpretations meanwhile Assessment Objective 2 is to explore how language, structure and form contribute to writers' presentation of ideas, themes and settings. Assessment Objective 1 is chosen as this research still focuses on the fundamental assessment of the competence.

The aim of this scheme is helping the writer to provide the closest guesses toward each answer of the reader, because it is stated that there is no correct answer in reader-response writing. It is because this research used the reader response-theory which believes that the readers produce their own meaning during the reading process.

\section{METHOD}

\section{A. Type of Research}

This research employs descriptive qualitative method. Qualitative method focuses on multi perspectives of analysis as well as concerns on inductive and deductive processes (Creswell, 2014). The results of the analysis in this method are in form of words (Kuswoyo \& Susardi, 2018) This type of research is selected because this research aims to see the variation of response as well as the scale of literary competence per students so that uniqueness of data can be observed.

\section{B. Research Subjects}

The subject of this research is 21 students of English Literature study program of Universitas Teknokrat Indonesia. These students are $4^{\text {th }}$ semester students taking the Prose Extrinsic Element course in the Academic Year of 
Competence Mapping through Reader-Response Writing Assessed using CCEA GCSE Mark Scheme

2019/2020. The Prose Analysis course is weighed 2 credit semesters and is aimed at developing critical thinking skills through prose analysis projects. The students were selected randomly by not considering their age and gender. These students have already passed the course of Introduction to Literary Study as well as Introduction to Prose.

\section{Research Instrument}

The instrument used in this research is exam test of reader-response writing on one of the stories from Anthology of Short Stories from Asian Writers third edition. The anthology is chosen for some reasons. First of all, the stories are written by some notable Asian writers. Hapsari (2011) stated that literary text in English class should consider the author of inner and outer circle as English is considered as international language, thus exposure of English text produced by outer circle region is also important. Second of all, the short stories describe Asian cultural, social, and religion contexts, which are considered close to students' life.

In addition, the story is a short story; therefore, it contains less complexity, less time consuming and less in number of pages which will be easier for the reader in reading it. Another instrument used in this research is the assessment rubric of CCEA GCSE English Literature Mark Scheme. This scheme is used by the lecturer to reveal and map readers' literary competence by looking at their responses. In this scheme, the quality of the readers written communication are set out into five broad criteria within the scheme; Band 5 (excellent), Band 4 (good), Band 3 (competent), Band 2 (emerging), band 1 (very little), and Band 0 (none).

\section{Research Procedure}

The data in this research is taken from students' assignments in the Prose Analysis course. At first, the researchers formulate questions derived from seven reader-response strategies, then adjust it to the CCEA GCSE English Literature Mark Scheme. Then, the researcher asks the course lecturer to instruct the students doing reader-response writing task. The lecturer of Prose Analysis course gives the assignment instructions, that is to analyze a story from Anthology of Asian writer using seven strategies of reader-response.

The lecture asks the students to read the short story in the class for 30 minutes. The students are instructed to write their responses at home and submit the assignment after three days through lecturer's online learning platform. The assignment of each student is labelled by the code "Reader 1 , 
"Reader 2", until "Reader 21". The answers from the students are grouped based on the strategies to make the data are easier to compare. In the last step, the students' literary competence is mapped and justified.

\section{RESULTS AND DISCUSSIONS}

\section{A. Reader-response Strategy Adaptation to CCEA GCSE English Literature}

CCEA GCSE English Literature Mark Scheme is used to map the students' literary competences whether they are in Band 0, Band 1 (Very Little), Band 2 (Emerging), Band 3 (Competent), Band 4 (Good), or Band 5 (Excellent). The maximum score for this rubric is 40 . The Mark Scheme is then adapted to seven reader response strategies from Beach and Marshal (1991) by distributing 40 points to 7 categories reflecting the seven strategies. Thus, each strategy has maximum score 4.71. In each strategy, there are two questions formulated by the researcher referring to the Assessment Objective 1.

\section{Table 1:}

\section{Questions for Reader-response writing}

\begin{tabular}{|c|c|}
\hline Strategy & Questions \\
\hline \multirow[t]{2}{*}{ Describing } & $\begin{array}{l}\text { Describe the direct and indirect presentation with the supporting } \\
\text { details. }\end{array}$ \\
\hline & Describe characters' characterization in the story. \\
\hline \multirow{2}{*}{ Describing } & Describe the setting of place and explain its influence to plot. \\
\hline & Describe the setting of time and explain its influence to plot \\
\hline \multirow{2}{*}{ Engaging } & What was felt by characters? Elaborate it. \\
\hline & What was thought by characters? Elaborate it. \\
\hline \multirow[b]{2}{*}{ Explaining } & State your agreement or disagreement to character's actions. \\
\hline & $\begin{array}{l}\text { Explain the reason of agreement or disagreement to character's } \\
\text { action }\end{array}$ \\
\hline \multirow[b]{2}{*}{ Interpreting } & What is the main idea of the story? \\
\hline & $\begin{array}{l}\text { Elaborate the reason why choosing the main idea by providing } \\
\text { supporting details. }\end{array}$ \\
\hline \multirow[b]{2}{*}{ Connecting } & Connect this story to self or others experience. \\
\hline & $\begin{array}{l}\text { Give the reason and explanation toward the experience you } \\
\text { connect. }\end{array}$ \\
\hline \multirow[b]{2}{*}{ Judging } & Give a judgment toward the moral values of the story. \\
\hline & $\begin{array}{l}\text { Elaborate the reason of choosing moral value with the } \\
\text { supporting details from story }\end{array}$ \\
\hline
\end{tabular}


Competence Mapping through Reader-Response Writing Assessed using CCEA GCSE Mark Scheme

Each question weighs 2,85 for the comprehensive answer. There are two other marks, 1,42 for incomplete or not comprehensive answer and 0 for no answer or unrelated answer, so a reader may get $0 / 1.42 / 2.85$ depending on the quality of their answer. Teacher mark this based on how students develop their answer in the assignment. After the responses of each student are marked, the total points are calculated, then the total points reflect in which band a student is in.

Table 2:

CCEA GCSE English Literature Mark Scheme

\begin{tabular}{|c|c|c|c|c|c|c|}
\hline \multirow{2}{*}{$\begin{array}{c}\text { Assessment } \\
\text { Objective }\end{array}$} & Band 0 & Band 1 & Band 2 & Band 3 & Band 4 & Band 5 \\
\hline & Mark 0 & $\begin{array}{c}\text { Very Little } \\
(1-10)\end{array}$ & $\begin{array}{c}\text { Emerging } \\
(11-18)\end{array}$ & $\begin{array}{c}\text { Competent } \\
(19-26)\end{array}$ & $\begin{array}{c}\text { Good } \\
(27-34)\end{array}$ & $\begin{array}{l}\text { Excellent } \\
(35-40)\end{array}$ \\
\hline \multirow[t]{4}{*}{$\begin{array}{l}\text { AO1 } \\
\text { Argument }\end{array}$} & \multirow[t]{4}{*}{$\begin{array}{l}\text { Response } \\
\text { not } \\
\text { worthy of } \\
\text { credit }\end{array}$} & \multirow[t]{3}{*}{$\begin{array}{l}\text { Some } \\
\text { writing } \\
\text { about text } \\
\text { and task }\end{array}$} & $\begin{array}{l}\text { Attempt to } \\
\text { focus on } \\
\text { question }\end{array}$ & $\begin{array}{ll}\text { Begin to } & \text { Some } \\
\text { focus on } & \text { focus } \\
\text { question } & \text { on } \\
& \text { questi } \\
& \text { on }\end{array}$ & $\begin{array}{l}\text { Sustained } \\
\text { focus on } \\
\text { question }\end{array}$ & $\begin{array}{l}\text { Persuasive, } \\
\text { coherent } \\
\text { answer to } \\
\text { question } \\
\text { set. }\end{array}$ \\
\hline & & & $\begin{array}{l}\text { Simple, } \\
\text { straightfor } \\
\text { ward, or } \\
\text { limited } \\
\text { response. }\end{array}$ & $\begin{array}{ll}\text { Begin to } & \text { Fairly } \\
\text { develop a } & \text { devel } \\
\text { response } & \text { oped } \\
& \text { respo } \\
& \text { nse }\end{array}$ & $\begin{array}{l}\text { Reasoned } \\
\text { response }\end{array}$ & $\begin{array}{l}\text { Evaluative } \\
\text { response }\end{array}$ \\
\hline & & & $\begin{array}{l}\text { Assertion, } \\
\text { basic } \\
\text { conclusion, } \\
\text { narrative or } \\
\text { description } \\
\end{array}$ & Some argument & $\begin{array}{l}\text { Developed } \\
\text { argument }\end{array}$ & $\begin{array}{l}\text { Sustained } \\
\text { argument }\end{array}$ \\
\hline & & $\begin{array}{l}\text { Very basic } \\
\text { level of } \\
\text { accuracy in } \\
\text { written } \\
\text { expression } \\
\text { and } \\
\text { coherence } \\
\text { of } \\
\text { response. } \\
\text { Form } \\
\text { mostly } \\
\text { appropriate }\end{array}$ & $\begin{array}{l}\text { Fairly } \\
\text { sound level } \\
\text { of accuracy } \\
\text { in written } \\
\text { expression } \\
\text { and } \\
\text { coherence } \\
\text { of } \\
\text { response. } \\
\text { Form } \\
\text { mostly } \\
\text { appropriate }\end{array}$ & $\begin{array}{l}\text { Competent level of } \\
\text { accuracy in written } \\
\text { expression and } \\
\text { coherence of } \\
\text { response. Form } \\
\text { mostly appropriate }\end{array}$ & $\begin{array}{l}\text { An } \\
\text { appropriat } \\
\text { e form of } \\
\text { response } \\
\text { which is } \\
\text { clearly } \\
\text { constructe } \\
\mathrm{d} \text { and } \\
\text { accurately } \\
\text { expressed }\end{array}$ & $\begin{array}{l}\text { An } \\
\text { appropriat } \\
\text { e form of } \\
\text { response } \\
\text { which is } \\
\text { clearly } \\
\text { constructe } \\
\mathrm{d} \text { and } \\
\text { expressed } \\
\text { with } \\
\text { fluency } \\
\text { and } \\
\text { precision }\end{array}$ \\
\hline
\end{tabular}

Because the research object is English Literature students in bachelor degree, the band should be either 4 (good) or 5 (excellent). It is due to their graduate 
profile that require them to do comprehensive analysis on the literary works supported by the detail information/textual evidence as well as the reasoning behind the selection of idea.

\section{B. Students' Performance in Reader-response Writing}

The implementation of students' literary competence mapping begins with observing students' response to New Asian Writing's 3rd Anthology of Stories published in 2013. It is based on seven strategies from Beach and Marshal (1991) namely describing strategies, engaging strategies, explaining strategies, interpreting strategies, connecting strategies, and judging strategies. The range of responses are varied in each strategy.

In the description stage, students were asked to describe the characterization and setting of the short story by addressing two questions. The first is "describe the direct and indirect presentation of the story with the supporting details" and the second is "describe characters' characterization in the story". There were sixteen students whose answers fulfilled the first and second questions by giving the detail information about the character and characterization and attached with the supporting detail of the story. Two students who partially fulfilled the first and second questions by only mentioning the character without explaining the characterization, and three students didn't give any answer.

In describing the setting, most of the readers were not able to answer question number two about the setting of time or place and its influence on the plot. The first question is "describe the setting of place and its influence to the plot" There were seven readers who only stated setting of place with no elaboration of its influence in the plot, and no students who can completely explain the influence. The rest of the students cannot identify the setting of the place. In terms of the second question, which is "describe the setting of time and its influence to the plot" only one student able to fulfill and it is partially fulfill the answer of the question, meanwhile the rest of them cannot identify the setting of time.

In engaging strategies, most of the readers were able to answer of "engage about what was felt by characters with the reason". Thirteen students are able to provide comprehensive answer, two students were only able to answer partially; however, three students cannot find any response toward this question. In "engage about what was thought by characters with the reason "question, thirteen students answer question completely fully as seen from their reader 
Competence Mapping through Reader-Response Writing Assessed using CCEA GCSE Mark Scheme

responses meanwhile two students can only meet it partially and six students cannot provide any answer. In explaining strategies, two questions were set, namely "Address agreement or disagreement to characters' actions "and "explain reason of agreement/disagreement to character action". All students fulfill these two questions but with different qualities. Seventeen students are able to explain their agreement or disagreement and the reason behind the agreement and disagreement completely meanwhile two of them answer in brief without supporting details. For example, they stated to agree with the characters' action but they do not state the reason or supporting detail to support their opinion in choosing agreement.

In the interpreting strategies, all the readers are able to address two questions. The first is "identify the statement of the main idea" and the second is "elaborate the reason why choosing the main idea (supporting details)". For the first and second questions, all students are able to fulfill them with 14 students partially fulfill and 7 students completely fulfill. Mostly, those who were not able to answer the question because they only state about the plot without any supporting detail from the story or connected with their personal judgement toward the story. Those who comprehensively answer stated the main idea and give the supporting detail to support their main idea. In connecting strategies, readers are required to address the question or "Connect self or others experience" and "explain the reason toward the experience". All students could answer these two questions. There are 16 who gave the best explanation for the question. Those readers answered the question correctly because they could make connection between their own experiences with the characters' experience, although some of the readers have the different experiences one and another. Three of them showed their comprehension toward connecting question by giving the explanation of other people's experience with the character's experience.

In the judging strategies, the questions should be addressed are "give a judgment of moral values" and "elaborate the reason of choosing moral value with the supporting details from story". Most of the readers were able to find moral value to be learned from the short story. There were 11 readers who were able to mention the moral value which is attached by the supporting detail such as quotation about why moral value was chosen. Furthermore, there are eight readers who are describing the moral value without giving any supporting detail that should be attached by the readers. The rest of the readers, were not able to answer the question because they only tell about the part of the story not stating the moral value. It can be summarized that mostly the readers were able to 
34 Celt: A Journal of Culture, English Language Teaching \& Literature, Volume 21, Number 1, June 2021, pp. 21 - 38

answer the last question by judging the moral value and attached with the supporting detail of the story.

\section{Level of Students' Literary Competence based on CCEA GCSE Mark Scheme}

The reflection of students' literary competence is taken from the total score student gained in reader-response writing assignment. The following table shows individual score of from Reader 1 until Reader 21 and student's each band.

Table 3:

Students' Literary Competence Result

\begin{tabular}{|c|c|c|c|c|c|c|c|}
\hline \multirow{3}{*}{$\mathrm{R}$} & \multirow{3}{*}{ Mark } & \multicolumn{6}{|c|}{ Competence } \\
\hline & & $\begin{array}{c}\text { Mark } \\
0\end{array}$ & $\begin{array}{l}\text { Very } \\
\text { Little }\end{array}$ & Emerging & Competent & Good & Excellent \\
\hline & & (0) & $(1-10)$ & $(11-18)$ & $(19-26)$ & $(27-34)$ & $(35-40)$ \\
\hline 1 & 22.8 & & +2 & & $\sqrt{ }$ & & \\
\hline 2 & 28.5 & & 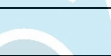 & 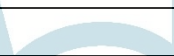 & 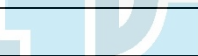 & $\sqrt{ }$ & \\
\hline 3 & 34.2 & & & 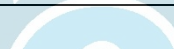 & 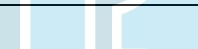 & $\sqrt{ }$ & \\
\hline 4 & 35.6 & & & 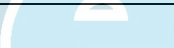 & & 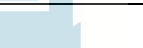 & $\sqrt{ }$ \\
\hline 5 & 24.2 & & 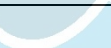 & 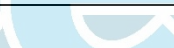 & $\sqrt{ }$ & 4 & \\
\hline 6 & 29.9 & 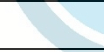 & O & 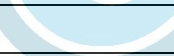 & 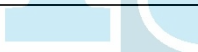 & $\sqrt{ }$ & \\
\hline 7 & 18.5 & & & $\sqrt{ }$ & 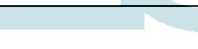 & & \\
\hline 8 & 34.2 & & & & & $\sqrt{ }$ & \\
\hline 9 & 28.5 & & & & & $\sqrt{ }$ & \\
\hline 10 & 15.6 & & & $\sqrt{ }$ & & & \\
\hline 11 & 27 & & & & & $\sqrt{ }$ & \\
\hline 12 & 31.3 & & & & & $\sqrt{ }$ & \\
\hline 13 & 31.3 & & & & & $\sqrt{ }$ & \\
\hline 14 & 31.3 & & & & & $\sqrt{ }$ & \\
\hline 15 & 25.6 & & & & $\sqrt{ }$ & & \\
\hline 16 & 24.2 & & & & $\sqrt{ }$ & & \\
\hline 17 & 25.6 & & & & $\sqrt{ }$ & & \\
\hline 18 & 27 & & & & $\sqrt{ }$ & & \\
\hline 19 & 22.8 & & & & $\sqrt{ }$ & & \\
\hline 20 & 19.9 & & & & $\sqrt{ }$ & & \\
\hline 21 & 25.6 & & & & $\sqrt{ }$ & & \\
\hline & otal & 0 & 0 & 2 & 9 & 9 & 1 \\
\hline
\end{tabular}


Competence Mapping through Reader-Response Writing Assessed using CCEA GCSE Mark Scheme

The table shows that there are no students in Band 0 and Band 1, 2 students are in Band 2, 9 Students in Band 3, 9 students in Band 4 and 1 student in Band 5. From the result, it is inferred that only 10 out of 21 students passed the minimum required Band. This band clearly reflects the students' current competence in literature especially in understanding prose. Based on the analysis of the answer sheet, students find the difficulty in answering the describing strategies and also facing difficulty to express the idea due to linguistics competence as EFL learners.

In term of content, most of the students were able to explain the setting but were not able to explain the influence of setting time and place of the story toward the plot. In other strategies, students are mostly able to answer the question; however, the quality of reasoning still needs improvement. The exposure of reasoning should always be trained in the class because through reasoning, the readers will develop their capacity to judge and conclude literary works (Gómez-Rodríguez, 2018). In this context, the students' score is mostly 1.42 out of 2.85 because the students still lack in explaining why they select certain main idea and why they select moral values in the story as well as the textual evidence. This result further can be used for lecturer to improve teaching processes addressing students' weaknesses in the strategies by providing more critical thinking practices in literary classroom as well as moral value and theme justification practices.

The success of creating students to be literary competent is highly influenced by their linguistic competence. Some of the students as EFL learners in this research were facing difficulty to arrange the responses in well-structured sentence. Comprehension of grammar and vocabulary hinder the student in expressing their ideas. Inan \& Boldan (2018) stated that the readers should have the necessary competence in terms of linguistic and experiential background. In the same vein, Hapsari (2011) also agrees that combination of linguistic, socio-cultural historical and semiotic awareness is important key in reader response. Therefore, exposure on reading symbol or semiotics should also be highlighted in literary classroom.

The level of students' literary competence can be further mapped for another unit. In CCEA GCSE, the other units are drama and Shakespeare, meanwhile poetry is not included. Therefore, it can also be included as one of important literary competences that needs to be mapped. In the following implementation, the literary competence can be formulated into competency-based test that are required for the students before they graduate 
from their major. Therefore, in the end, they have authorized certificate describing the level of English literary competences.

\section{CONCLUSION}

CCEA GCSE Mark Scheme for English Literature for Prose along with Beach and Marshal's reader response writing can be used as an alternative for mapping students' literary competition for tertiary education students taking English Literature major. Through adaptation of scoring and assessment criteria, the assessment model is able to map in which band each student's competence is in. Through this mapping, students are then can be directed for further treatment, especially those who cannot achieved minimum band.

The literary competence mapping in this research has been conducted limitedly for the prose unit and for Assessment Objective 1 (AO1). Further researches might highlight the implementation in poetry, and drama as they are the core of literary works learned in English Literature study program. Assessment Objective 2 (AO2) for the prose and other literary works might also become research direction.

\section{ACKNOWLEDGEMENT}

This research is fully funded by Universitas Teknokrat Indonesia through Internal Research Grant 2020/2021.

\section{REFERENCES}

Afifudin, M. (2016). Engaging Literary Competence through Critical Literacy in an EFL Setting. Ninth International Conference on Applied Linguistics (CONAPLIN 9) pp. 131-134. Atlantis Press. doi:https://doi.org/10.2991/conaplin-16.2017.28

Aloqaili, A. S. (2012). The relationship between reading comprehension and critical thinking: A theoretical study. Journal of King Saud Univesity Languages and Translation, 24, 35-42.

Beach, R., \& Marshall, J. (1991). Teaching literature in the secondary school. San Diego: HJB. 
Competence Mapping through Reader-Response Writing Assessed using CCEA GCSE Mark Scheme

Boong, J. (2012). Study: Fictional Characters will Influence. Ohio: Ohio State University.

Bressler, C. (1999). Literary Criticism: An Introduction to Theory and Practice, Second Edition. Pittsburgh: Prentice-Hall Inc.

Brownie, J., Thomas, M., \& Bahnisch, M. (2011). Exploring the Literature: Competency-based Education and Training $\mathscr{E}$ Competency-Based Career Frameworks. Quensland: University of Quensland.

CCEA. (2017). General Certificate of Secondary Education English Literature Unit 1: The Study of Prose. Retrieved from GCSE English Literature: https://ccea.org.uk/key-stage-4/gcse/subjects/gcse-english-literature-201 7/past-papers-mark-schemes

Creswell, J. (2014). Research Design: Qualitative, Quantitative, and Mixed Methods Approaches. California: SAGE Publications.

Culler, J. (2000). Literary Theory: A Very Short Introduction. Oxford: Oxford University Press.

Denning, D. S. (2020). What is Story? What is Narrative Meaning? Retrieved from http://

www.stevedenning.com/Business-Narrative/definitions-of-story-and-narr ative.aspx.

Gomez-Rodriguez. (2018). English Learners' Literary Competence Development through Critical Thinking Tasks in a Colombian EFL Classroom. International Journal of Applied Linguistics 8 English Literature, $7(7), 3-13$.

Hapsari, A. (2011). Literary Competence for The Teaching of Literature in Second Language Educational Context. Journal of English and Education, 5(10), 29-36. doi:10.20885/jee.vol5.iss1.art2

Inand, D., \& Boldan, M. (2018). Implementation of Reader-Response Theory in Teaching Short Story. . The Literary Trek, 4(2), 63-76.

Iskhak, I. (2015). The Application of Reader-response Theory in Enhancing Student Teachers' Affective and Linguistic Growth: A Classroom Action Research in EFL Teacher Education in Indonesia. The English Teacher, 44(2), 43-55. 
Kuswoyo, H., \& Susardi, S. (2018). Thematic Progression in EFL Students' Academic Writings: A Systemic Functional Grammar Study. Teknosastik, 14(2), 39. doi:https://doi.org/10.33365/ts.v14i2.60

Mart, C. T. (2019). Reader-Response Theory and Literature Discussions: a Springboard for Exploring Literary. The New Educational Review, 78-87. doi:10.15804/tner.2019.56.2.06

Mladkova, L. (2013). Leadership and Storytelling. The 2nd International Conference on Leadership, Technology, and Innovation Management (pp. 83-90). Prague: Elsevier.

Ningrum, C. H. (2018). The Use of Reader-Response Theory to Teach Reading Narrrative Text for Tenth Graders of Senior High School. Retain, 6(1), 95-103.

Prahaladaiah, D. (2018). A Study on Developing Reading, Literary Competence and the Communicative Approach. (Quest Journals) Journal of Research in Humanities and Social Science, 6(2), 08-10.

Rosenblatt, L. (1982). The literary transaction: Evocation and response. Theory into practice (Vol. 24). doi:10.1080/00405848209543018

Samanik, S. (2018). Teaching English Using Poetry: An Alternative to Implement Contextual Teaching and Learning. Journal of ELT Research, 3(1), 21-28.

Spiro, J. (1991). Assessing Literature: Four papers. In B. C, Assessment in Literature Teaching (pp. 16-83). Basingstoke: McMillan Publisher.

Suprayogi, S., \& Pranoto, B. E. (2019). Students' Perspectives Toward News Voiceover Activity in Pronunciation Class. Twelfth Conference of Applied Linguistics 2019 (pp. 203-206). Atlantis Press.

Žbogar, A. (2015). Reading ability and literary competence in language arts classes in Slovenia. Croatian Journal of Education, 17(4), 1219-1247. doi:https://doi.org/10.15516/cje.v17i4.1271 